\author{
Olha Lukova \\ National Scientific Centre "Institute of Agrarian Economics", Kyiv, Ukraine \\ E-mail: lukova.olga@gmail.com \\ ORCID: https://orcid.org/0000-0002-6105-6265
}

\title{
Identification of financial instruments as an object of accounting
}

\begin{abstract}
Financial instruments, which appeared in the international arena of accounting regulations in October 1986, are still considered one of the most complex objects of accounting. The difficulties of their accounting recording are often associated with a complicated regulation of the relevant issue within international and national standards for accounting and financial reporting. At the same time, one ignores the fact that these specific objects of accounting have been used in the economy much earlier than their accounting regulations are formed. Not least important is the aspect that financial instruments have a contractual nature, which determines the dependence of their identification as an object of accounting on professional judgment. The purpose of the research is to cover the preconditions for the emergence of financial instruments in the accounting system and elucidate the reasons for the complexity of their identification as an object of accounting. The subject of the research is the theoretical background of the identification of financial instruments as an object of accounting. This research has theoretical nature that predetermined a set of methods for its conducting, as follows: analysis - to distinguish between the industrial, financial, and digital epochs and establish the relevance of financial instruments to them; abstraction and comparison - to clarify the peculiarities, common and distinctive features of accounting recording of financial instruments in the production, financial and digital eras; graphical method - to visualize the sequence of the emergence of the financial instruments in accounting and the identified contradictions when recording them in the balance sheet. The application of the mentioned methodology allowed elucidating the prerequisites for the emergence of financial instruments in accounting and specifying the reasons for the complexity to identify financial assets, financial liabilities, and equity instruments as objects of accounting. Approaches, which have been formed in the accounting system during the predominance of assets of the real economy, do not undergo the necessary transformations and adaptations to the objects that represent a virtual component of the economy. Moreover, the balance sheet as the basic form of financial reporting of any enterprise still reflects the production era, which gave way to the financial and digital ones.
\end{abstract}

\author{
Keywords \\ Balance, equity instruments, \\ derivative financial \\ instruments, financial assets, \\ financial liabilities, financial \\ instruments
}

JEL: M40, M41, G30

\section{Introduction}

The change in the economic structure and the predominance of new incentives for the development of economic relations have not found due consideration in accounting theory. Financial instruments, which are still considered the most complex objects of accounting for various reasons, are a striking example of the above. Among them are highlighted the complexity of regulation which is specified within international and national standards for accounting and financial reporting.

On the one hand, a lack of regulatory "simplicity" in this field of accounting can be explained by the nature of financial instruments, which does not allow one to apply standard approaches to them and requires subjective assessment, and therefore, their accounting is significantly dependent on professional judgment. However, on the other hand, other objects of accounting (in particular, intangible assets) have an atypical (special) nature of origin, but they have clear identification, own financial accounts and other attributes of the accounting object.

Taking into account the above, it seems logical to assume that the reason for the complexity of identifying financial assets, financial liabilities and equity instruments as financial instruments lies not only in the fact that these objects of accounting are components of the virtual component of the economy. Thus, the tasks of this research are:

- to identify the prerequisites for the emergence of financial instruments in accounting;

- to elucidate the reasons for the complexity of identifying financial assets, financial liabilities and equity instruments as the objects of accounting.

To achieve the mentioned goals, it is necessary to study the periods of origin and formation of financial instruments in accounting taken in conjunction with the dominants that determine the trajectory of economic and social development over a defined long period and specify the features of their accounting recording in the relevant periods.

\section{Historical review}

Investment activity, risk insurance, access to financial resources, and fund raising are inextricably linked to financial instruments today. They continue to become more 
widespread and secure the status of an essential element of the global economy. In addition, modern capital markets are filled with more advanced types of financial instruments, which often exceed the scope of the available accounting methodology.

However, it cannot be claimed that financial instruments have always played that sort of role in economic performance. Until a certain period, the development of economic relations has been carried out without their involvement. At the same time, at the moment, there is no a clear and reasonable understanding of the future role of financial instruments in economic processes at the national and global levels. The drive of any processes and operations towards digitalization, the rapid transition to the digital economy, and ensuing restructuring in economic relations will inevitably lead to changes in the use of these tools.

Historical analysis of the evolution of economic relations indicates that their advancement is depended on various factors. However, only some of them had played an integral role and set the vector of economic and social development for a long time. In particular, in different periods, it was production (real / industrial capital), finance (financial capital), and now it is about digitalization (digital capital). Moreover, the transition to a new era does not mean the elimination of a particular type of capital. On the contrary, capital is preserved, and its role changes (the dominant position passes to another type).

Given the above, one can distinguish three main eras of economic relations:

1) production era (first, manual production, and later industrial);

2) financial era (relations concern the distribution and redistribution of monetary resources);

3) digital era (digital technologies, artificial intelligence, blockchain, robots, Internet of things).

Thus, the dominants, which for a long period determined the trajectory of economic and social development, are chosen as a criterion for the division into epochs.

The production era was characterized by the rendering of typical objects of assets, liabilities, and capital in accounting records. A clearly defined balance sheet formula was observed: the asset is equal to the liability $(A=L)$, or the asset is equal to the capital plus liabilities $(\mathrm{A}=\mathrm{C}+\mathrm{LS})$. Various balance sheet theories that interpret the above formula are worked out and consolidated in the theoretical dimension of accounting. Accounting is carried out under specific rules - instructions.

Financial instruments are not separated into individual groups, which are not represented in accounting records or reports. They are scattered among non-current and current assets, types of capital, and liabilities. In other words, in the production era, financial instruments, before being identified per se, were available in accounting but did not have an individual reflection and were introduced as part of other objects of accounting (e.g., promissory notes, loans, accounts receivable/payables, cash, etc.).

In the financial era, the role of banks which diverted funds, including those obtained from industry, increased. Thus, financial instruments and credit allowed fund proprietors to augment both production (by engaging one's own and borrowed assets in production) and financial capital.

In the financial era, when financial instruments came to the fore and began to play an important role in the capital movement, they were already identified in accounting, their classification was formed, rules about the reflection of information about them in accounting and disclosure in financial statements were prescribed.

However, during that period, the identification of financial instruments remained challenging; there was a weakness of theoretical basis and significant dependence on professional judgments (this, in turn, refers to professional competence, decency, and the need to comply with the professional code of ethics).

The digital era replaced the financial one. It was conditioned by the formation of a new perception of economic processes, which is called the digital economy. The digital economy is "a new economic structure based on knowledge and digital technologies under which new digital skills and opportunities of society, business, and the state are developed" (Vsemirnyi bank, 2016).

The digital era is marked by progress and the defining role of digital capital. The works by the French sociologist P. Bourdieu initiated the study of the relevant concept. According to the scientist, the essence of digital capital is reduced to the formation of specific "structures of domination", which provide individuals with the ability to accomplish their plans and achieve their goals (Bourdieu, 1993).

The digital era is characterized by the emergence of new objects for accounting, in particular, digital money, the use of which is already in practice, and setting the trend of alterations in all sectors of the economy through digitalizing processes. There appear new technologies aimed at working with data (e.g., Big Data, Blockchain, Internet of Things, etc.) which cannot but affect the functioning of accounting and thus its theory and practice of separating new objects, their fixation, evaluation, reflection, etc.

With this in mind, the beginning of the digital era and the predominance of digital capital would have to provoke the evolution of modern approaches to the identification of new objects of accounting and mean the change (or its lack thereof) of the role of financial instruments. However, the opposite situation is observed: nowadays, these processes are not found in the standards (international and national) and accounting practices.

Moreover, financial instruments, which are available in accounting as individual objects, are devoid of special identification and entirely dependent on the professional judgment and interpretation of the accountant. A great deal of financial instruments is also characterized by a lack of individual specification in the balance sheet (e.g., receivables, payables, shares, etc.). There is no doubt that all financial assets, financial liabilities, and equity instruments are conveyed in the balance sheets of enterprises, but they are largely "hidden" among other assets, liabilities, and types of capital.

Thus, the historical evolution of financial instruments among the objects of accounting can be traced in Figure 1

\section{Representation of financial instruments on the balance sheet}

Financial instruments (at least some of their types), which are currently singled out by the International Financial Reporting Standards and national accounting regulations (standards), have appeared much earlier than their accounting regulation, as well as their identification, separation and reporting disclosure. 


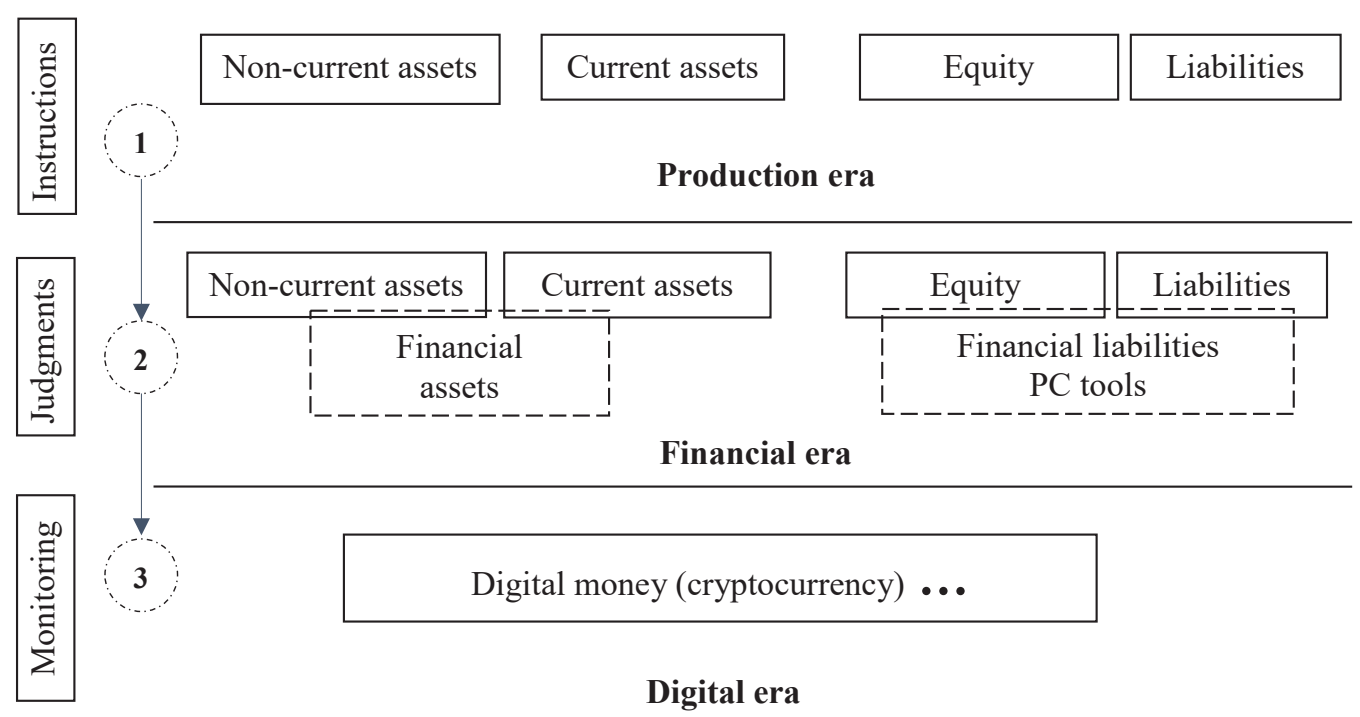

FIGURE 1 Financial instruments among the objects of accounting: historical development Source: author's development

For instance, metal money had originated in the 7 th century BC. Money as a credit instrument (credit money) came into operation in the second half of the seventeenth century. The earliest forms of promissory notes had been used in Italy in the thirteenth and fourteenth centuries (Moshenskyi, 2005). At the same time, there was the establishment of International Accounting Standard 39 (IAS 39) - the publication of its draft dates back to October 1986 (IAS 39). As for domestic practice, the appearance of UAS 13 "Financial Instruments" took place in November 2001.

The above chronology clearly illustrates that the accounting regulations, the development of the accounting rules and the representation of a potential object of accounting in the balance sheet have been formed much later than its appearance. In practice, financial instruments have long been used: they are in circulation, enterprises use them as tools for controlling risk and capital redistribution, but the accounting realm has been either not separated or lacked them for some time. This indicates that user queries were generated, but accounting science and practice could not offer the best way to render these objects in the accounting and reporting system. The cause may lie in the conservative approach to the use of elements of the accounting method and prove their obsolescence.

The complexity of financial instruments of accounting is conditioned by their contractual nature. This conveys the interpretations of the concept and their classification proposed by accounting standards.

Thus, according to UAS 13 "Financial instrument", a financial instrument is a contract that simultaneously gives rise to (increases) a financial asset in one enterprise and a financial liability or equity instrument in another (Minfin Ukrainy, 2001). Such interpretation of financial instruments triggers the following question: how a financial instrument that "gives rise to" a financial asset, financial liability or equity instrument, can be the same financial assets, financial liabilities, and equity instruments (the classification defined in the standards expressly points to this fact)?

If a financial instrument "gives rise" to a financial asset, financial liability or equity instrument, the instrument cannot be one what it generated. Following the definition outlined the UAS and IAS, it appears that the financial instrument must be transformed into another - a new object of accounting, i.e., the stipulation of the origin. The causality of this process stresses that both in the former case - the emergence of a new element, and in the latter case - an alteration, the financial instrument is no longer what it was at the initial stage. However, the classification mentioned in the standards emphasizes the opposite.

Moreover, financial assets and financial liabilities as classification groups of financial instruments are already represented in accounting by other items. In particular, cash and cash equivalents are current assets that are rendered in the third-class accounts, i.e., 30 "Cash"; and 31 "Bank accounts". A contractual obligation to transfer cash is a long-term or current obligation that can be recorded in the fifth-and sixth-class accounts, e. g., 50 "Long-term loans", 53 "Long-term lease obligations", 63 "Settlements with suppliers and contractors", or 68 "Settlements for other transactions".

Consequently, the accounting system and its registers practically record not the financial instrument itself (a trigger contract) but its components (derivatives) - a financial asset and financial liability, or equity instrument. The contradiction inherent in the interpretation of the concept of financial instruments and their classification carries the risk of inflating enterprise balance.

However, it should be noted that the purpose of financial instruments differs from the purpose of other assets and liabilities. Thus, initial recognition or writing-off liabilities (e.g., fixed assets, inventories, etc.) is the result of the transition of risks and rewards of ownership from one entity to another. Financial instruments go along with the distribution of risks and benefits between the parties to the contract.

Based on the above, it seems logical to assume that the separation of financial instruments as an individual object of accounting is an attempt to convey the same assets / liabilities from different angles (depending on their nature and purpose) at different stages of change of the components of assets or liabilities of the balance sheet of the enterprise. 


\section{PRODUCTION ERA}

The balance sheet of the era of industrial capital

FINANCIAL ERA
\begin{tabular}{c|} 
The balance sheet of the era of industrial capital \\
DIGITAL ERA \\
The balance sheet of the era of industrial capital \\
FIGURE 2 The evolution of a balance sheet as the main form \\
of reporting in the production, financial and digital eras
\end{tabular}
Source: author's development

At the same time, such an attempt currently faces implementation difficulties, which are described above, and is conditioned, in particular, by the fact that the way of building a balance sheet is outdated, one that aims to meet user needs of the production era (the era of industrial (production) capital). During that period, there was a lack of availability and applicability of financial instruments as part of the virtual economy, and some of them played a completely different role than today (Figure 2).

As shown by Figure 2, there is a change of epochs and objects of accounting, but the balance sheet remains fixed. Therefore, the emergence of new objects of accounting (of financial, digital, or subsequent epochs) requires revising application of established approaches to their separation, identification, presentation, as well as changes in the formation of a balance component of financial statements to render business transactions, processes, relations, etc. accurately and fully in the accounting system.

\section{Conclusions}

The emergence of financial instruments in accounting is conditioned not so much by the expansion of areas of their application as the willingness and ability of accounting science and practice to offer the best way to convey these objects in the system of accounts and reporting. The cause may lie in the conservative approach to the use of elements of the accounting method and prove their obsolescence.
The main reasons for the complexity to identify financial assets, financial liabilities, and equity instruments as objects of accounting are the statutory interpretation of financial instruments, which contains contradictions with the classification proposed in the standards, scattered presentation at a balance sheet, high level of dependence on professional judgment.

Financial instruments have a contractual nature. This means not only that only a particular contract can be recognized as a financial instrument but also that the content of that contract (since the contract is an agreement of the parties on a particular subject-matter and thus the procedure, conditions and terms) directly affects the identification of the financial instrument (financial asset, financial liability or equity instrument), its classification and presentation at the financial statements.

Approaches, which have been formed in the accounting system during the predominance of assets of the real economy, do not undergo the necessary transformations and adaptation to the objects that represent a virtual component of the economy. Moreover, the balance sheet as the main form of financial reporting of any enterprise remains an echo of the production era, which gave way to the financial and digital ones. This confirms the obsolescence and inconsistency of the current reporting structure with the modern needs of its users and the need to revise the application of established approaches to the use of elements of the accounting method and building the balance component of reporting.

\section{References}

[1] Bourdieu, P. (1993). Sotsiolohiya politiki [Sociology of politics]. Moscow: Socio-Logos. (in Russian)

[2] IAS 39 - Financial Instruments: Recognition and Measurement. E-source: https://www.iasplus.com/en/standards/ ias/ias39

[3] Minfin Ukrainy (2001). Natsionalne polozhennia (standart) bukhhalterskoho obliku 13 «Finansovi instrumenty» [National accounting standard 13 "Financial Instruments"]. E-source: https://zakon.rada.gov.ua/laws/show/z105001\#Text (in Ukrainian)

[4] Moshenskyi, S. Z. (2005). Evoliutsyia vekselia [Evolution of a bill]. Kyiv: Rovno: Planeta-druk. (in Russian)

[5] Vsemirnyi bank (2016). Razvitie tsyfrovoi ekonomiki v Rossii [Development of the digital economy in Russia]. E-source: http://www.vsemirnyjbank.org/ru/events/2016/12/20/developing-thedigital-economy-in-russia-internationalseminar-1 (in Russian) 